\title{
Study on the emission characteristics and mechanism of sulfur-containing gas during sludge pyrolysis at low temperature
}

\section{Shuo Shang}

Xi'an University of Architecture and Technology

Haihong Fan ( $\sim$ fanhaihongfu@163.com )

Xi'an University of Architecture and Technology

Binbin Li

Xi'an University of Architecture and Technology

Lin Li

Xi'an University of Architecture and Technology

Zhou Li

Xi'an University of Architecture and Technology

\section{Research Article}

Keywords: sludge pyrolysis, sulfur-containing gas, calcium-based ultrafine powder, absorption and adsorption

Posted Date: September 3rd, 2021

DOI: https://doi.org/10.21203/rs.3.rs-840676/v1

License: (c) (i) This work is licensed under a Creative Commons Attribution 4.0 International License. Read Full License 


\section{Abstract}

The effects of temperature, time, and calcium-based ultrafine powder on sulfur-containing gas in the sludge drying process were examined through experiments, and effective measures to control the release of sulfur-containing gases such as $\mathrm{CS}_{2}, \mathrm{H}_{2} \mathrm{~S}$, and $\mathrm{SO}_{2}$ were proposed. Experimental results showed that the drying temperature of sludge should be controlled below $250^{\circ} \mathrm{C}$, and the drying duration should be kept within $1 \mathrm{~min}$. Additionally, the release amount of three gases released was small. When the addition amount of calcium-based powder added reached $20 \%$ of the original sludge mass fraction, the concentration of sulfur-containing gas released was $59.81 \mathrm{mg} / \mathrm{m}^{3}, 94 \%$ lower than that of the dry pure sludge gas. After absorption by calcium-based powder, there are almost no sulfur-containing organic compounds and sulfur-containing gases. The research results provide a direction for the selection of pyrolysis sludge treatment technology, which is conducive to control the discharge of harmful gases.

\section{Introduction}

With the acceleration of urbanization, the output of sludge continues to rise and reach $60-90$ million tons by 2020 in China (Liu et al., 2020; Yin et al., 2019). It is crucial to find appropriate ways to reuse these wastes to reduce their impacts on environment. The most common disposal options of sewage sludge are landfill, land diffusion, and incineration (Kelessidis, A and Stasinakis, A. S., 2012; Svanström, M et al., 2005). As the moisture content of sludge is $\sim 80 \%$, a drying process is required for the harmless reduction and resource treatment of sludge (Lu et al.,2014; Liu et al.,2012). However, the inevitable odor emissions that are unavoidable during drying may raise concerns about environmental pollution and human health. There are eight kinds of odorous gases that must be strictly controlled and detected in the emission standard for odor (GB 14554-93). Five of them are sulfur-containing compounds, namely, $\mathrm{H}_{2} \mathrm{~S}, \mathrm{CH}_{3} \mathrm{SH}$, $\mathrm{C}_{2} \mathrm{H}_{6} \mathrm{~S}, \mathrm{CS}_{2}$, and $\mathrm{C}_{2} \mathrm{H}_{6} \mathrm{~S}_{2}$. The influence of sulfur on sludge in the treatment and disposal process should not be underestimated, such as the corrosion of infrastructure caused by sulfur gas emission, the speciation regulation of metals (such as $\mathrm{Cu}, \mathrm{Zn}$ and $\mathrm{Ag}$ ), and the undesirable gases produced in the biological treatment process (Luo et al., 2014; Donner et al., 2011; Zhang et al., 2008). Therefore, we need to pay attention to the release and control of sulfur gas in sludge pyrolysis.

S in wasted sludge is primarily constituted of S-containing biomolecules (e.g., amino acids with Scontaining side chains), inorganic sulfides, and insoluble sulfate (Lin et al., 2014; Du and Parker, 2013; Dewil et al.,2008; Svanström et al., 2005). Compared with most biomass, the characteristics of sludge related to thermochemical conversion during pyrolysis are more complex and different (Thipkhunthod et al., 2007). Liu et al. (2015) showed that the release of sulfur-containing odor gases from sludge comes from two processes: the first is mainly the inorganic sulfur release process of free sulfur-containing gas molecules from inorganic sulfur, and the second is the decomposition of sulfur-containing organic matter caused by the heating of sludge and the release of organic sulfur, which produces sulfur-containing polluting gases. During pyrolysis, aliphatic-S and sulfonate were preferentially degraded at low temperature (below $350^{\circ} \mathrm{C}$ ) and sulfate was thermochemically reduced at a temperature above $450^{\circ} \mathrm{C}$, 
while metal sulfides (up to 27\%) and thiophenes (up to $70 \%$ ) were increasingly formed (Huang et al.,2021). If these sulfur-containing gases are directly discharged without control and treatment, it will cause great harm to human health and life. It is reported that the main sulfur-containing gases released during a sludge drying process were $\mathrm{H}_{2} \mathrm{~S}$ and $\mathrm{SO}_{2}$, and they accounted for $82.4 \%$ of the total gas released (Liu et al., 2012). Cheng et al. (2017) selected two representative organic sulfides-BS and DHS-to conduct pyrolysis experiments of sludge and $\mathrm{NaOH}$ at different temperatures. They discussed the organic sulfide model after adding alkali and analyzed its transformation effect. In particular, Liu et al. (2014a) proposed that $\mathrm{CaO}$ could significantly improve the conversion of sludge into coke and combustible gases (especially $\mathrm{H}_{2}$ and $\mathrm{CO}$ ) and explained the effect of $\mathrm{CaO}$ on sulfur conversion during pyrolysis. It is found that adding $\mathrm{CaO}$ to sludge will result in deoxidation reaction, reducing O-containing compounds in organic matter and adsorbing $\mathrm{CO}_{2}$ from noncondensable gas (Udayanga et al., 2019).

Several scholars are currently interested in the release mechanism of sulfur gas produced during a drying process; however, the absorption and inhibition mechanism of sulfur gas release have not been studied in-depth, and there are no effective control methods for the odor gases released in a drying process. This study focuses on the production technology of "Using a cement kiln tail system to atomize and dry sludge-cement rotary kiln to incinerate and dry sludge" (proposed by Powder Engineering Institute of X'an University of Architecture and Technology) and explores how different factors influence odor emission. The research results have a new understanding of the release characteristics of sulfurcontaining gas in the process of sludge low-temperature pyrolysis, and the measures to control the emission of sulfur-containing gas have been proposed.

\section{Experimental}

\subsection{Experimental materials and properties}

Table 1 shows the elemental composition of the sludge and Table 2 shows the chemical composition of calcium-based powder used in the experiment. CBP is obtained from the flue gas produced by the kiln of a cement plant. The maximum particle size of CBP is $12 \mu \mathrm{m}$, the average particle size is $3.12 \mu \mathrm{m}$, and the particle size of $90 \%$ of the powder is less than $6.88 \mu \mathrm{m}$.

Table 1

Element Composition of Sludge (RS)\%

\begin{tabular}{|llllllllllll|}
\hline Element & $\mathbf{C}$ & $\mathbf{H}$ & $\mathbf{0}$ & $\mathbf{N}$ & $\mathbf{S}$ & $\mathbf{S i}$ & $\mathbf{C a}$ & $\mathbf{A l}$ & $\mathbf{F e}$ & $\mathbf{K}$ & $\mathbf{M g}$ \\
\hline Composition & 30.65 & 6.14 & 20.13 & 3.96 & 1.81 & 14.45 & 6.25 & 5.7 & 8.84 & 3.24 & 2.18 \\
\hline
\end{tabular}

Table 2

Chemical Composition of Calcium Based Powder (CBP)\%

\begin{tabular}{|llllllllll|}
\hline $\mathrm{SiO}_{2}$ & $\mathrm{Al}_{2} \mathrm{O}_{3}$ & $\mathrm{Fe}_{2} \mathrm{O}_{3}$ & $\mathrm{CaO}$ & $\mathrm{MgO}$ & $\mathrm{K}_{2} \mathrm{O}$ & $\mathrm{Na}_{2} \mathrm{O}$ & $\mathrm{SO}_{3}$ & Loss & Sum \\
\hline 13.87 & 2.52 & 1.74 & 42.56 & 2.18 & 0.68 & 0.06 & 0.48 & 35.02 & 99.11 \\
\hline
\end{tabular}




\subsection{Experimental instruments and methods}

The experimental system shown in Fig. 1(a) was used to study the effect of sludge temperature and time on the release of sulfur gas. $\mathrm{N}_{2}$ is used as a carrier for gas transport gas. After the sludge is dried, the content of $\mathrm{CS}_{2}, \mathrm{H}_{2} \mathrm{~S}$, and $\mathrm{SO}_{2}$ in the absorption solution is measured by a spectrophotometer method, and the total amount of each gas released by the quantitative sludge is calculated. The experimental schemes of temperature and time are as follows:

1. Temperature effect experiment: $0.5 \mathrm{~g}$ of sludge was put into a $250 \mathrm{ml}$ three-port flask, and the temperature of the heating jacket was controlled at $150^{\circ} \mathrm{C}, 200^{\circ} \mathrm{C}, 250^{\circ} \mathrm{C}, 300^{\circ} \mathrm{C}$, and $350^{\circ} \mathrm{C}$, respectively, for $10 \mathrm{~min}$.

2. Time effect experiment: $0.5 \mathrm{~g}$ sludge was put into a $250 \mathrm{ml}$ three-port flask, the temperature of the heating jacket was adjusted to $250^{\circ} \mathrm{C}$, and the heating time was $0.5,1,1.5,2,3,4,5$, and $10 \mathrm{~min}$, respectively.

The influence of calcium-based ultrafine powder on sulfur-containing gas is shown in the sludge drying experimental system in Fig. 1(b). CVT-1600PC sintering analyzer is the main equipment used to test and record the change of sludge quality during the drying process. The system temperature is controlled by the control system operated by the PC. The dried gas is collected and stored in a gas sampling bag for detecting gas concentration, except for $\mathrm{NH}_{3}$. Specific experimental steps are as follows:

The material RS and CBP were mixed in order of $0,20: 1,10: 1$, and $5: 1$ and then put into the sintering analyzer for testing. At a room temperature of $20.8^{\circ} \mathrm{C}$, the air in the furnace is pumped to $0.06 \mathrm{MPa}$ using a vacuum system and then heated to $200^{\circ} \mathrm{C}$ and $250^{\circ} \mathrm{C}$ at a heating rate of $5^{\circ} \mathrm{C} / \mathrm{min}$ for $60 \mathrm{~min}$. The hightemperature mixed gas is transferred through the upper exhaust valve of the sintering analyzer and collected after cooling and drying. The concentration of $\mathrm{H}_{2} \mathrm{~S}$ gas is determined using gas

chromatography. Additionally, the gas released from pure sludge heated and dried at $300^{\circ} \mathrm{C}$ was collected and adsorbed using CBP. The concentration of $\mathrm{H}_{2} \mathrm{~S}$ gas was determined and the change of raw material quality was recorded.

\section{Results And Discussion}

\subsection{Effect of temperature on odor emission}

As shown in Fig. 2, the release characteristics of main sulfur-containing odors $\mathrm{CS}_{2}, \mathrm{H}_{2} \mathrm{~S}$, and $\mathrm{SO}_{2}$ with drying temperature were measured via the spectrophotometer method.

It shows that although the release of $\mathrm{CS}_{2}$ is not large during the drying process, the growth rate with increasing temperature is large because $\mathrm{CS}_{2}$ is produced by the reaction of $\mathrm{CH}_{4}$ and $\mathrm{FeS}$ and the reaction rate increases with increasing temperature; however, the peak temperature of $\mathrm{CS}_{2}$ formation is $500^{\circ} \mathrm{C}$. In the temperature range of $150^{\circ} \mathrm{C}-350^{\circ} \mathrm{C}$ and $10 \mathrm{~min}$, the release of $\mathrm{CS}_{2}$ increased from 17 to $27.2 \mu \mathrm{g} / \mathrm{g}$, 
which is an increase of $62.5 \%$. When the temperature is lower than $200^{\circ} \mathrm{C}$, the release amount of $\mathrm{H}_{2} \mathrm{~S}$ gas released is less than $50 \mu \mathrm{g} / \mathrm{g}$, whereas when the temperature is higher than $200^{\circ} \mathrm{C}$, the release amount of the gas released rapidly increases sharply, reaching $386.25 \mu \mathrm{g} / \mathrm{g}$ at $250^{\circ} \mathrm{C}$. This is because of the large amount of organic acids produced in this temperature range, which transforms inorganic sulfides into $\mathrm{H}_{2} \mathrm{~S}$ or decomposes a large amount of organic sulfides(Ros et al., 2006). When the temperature rises above $250^{\circ} \mathrm{C}$, the growth of $\mathrm{H}_{2} \mathrm{~S}$ becomes more gradual and, eventually, constant. According to the influence of drying temperatures on $\mathrm{SO}_{2}$ emission, when the temperature is less than $250^{\circ} \mathrm{C}, \mathrm{SO}_{2}$ release is slow and less intense. When the temperature reaches $300^{\circ} \mathrm{C}, \mathrm{SO}_{2}$ emission increases from 88.74 to $307.81 \mu \mathrm{g} / \mathrm{g}$, an increase of $\sim 300 \%$. This is because a large amount of $\mathrm{SO}_{2}$ is produced by the decomposition of sulfur-containing aliphatic compounds at $300^{\circ} \mathrm{C}$, and then, with the increase in temperature, the release amount of $\mathrm{SO}_{2}$ increases growth is extremely slow.

To conclude, controlling the drying temperature of sludge should be controlled below $250^{\circ} \mathrm{C}$ reduces the release of the three gases is less.

\subsection{Effect of time on odor emission}

It can be seen from Fig. 3 that the release characteristics of the main sulfur gases $\mathrm{CS}_{2}, \mathrm{H}_{2} \mathrm{~S}$, and $\mathrm{SO}_{2}$ with drying time were measured via the spectrophotometer method. The figure shows that as time passes, the amount of the three gases released increases continuously, with the gas release amount of gas released increasing significantly at $30 \mathrm{~s}$ and tending to be constant at $10 \mathrm{~min}$, and there is almost no gas was released afterward. This is due to heat transfer between the materials as the sludge is stacked in the three beakers. It takes a certain amount of time to heat the sludge to be heated from room temperature to $250^{\circ} \mathrm{C}$. The sludge release rate is low during this time. When the sludge temperature reaches $250^{\circ} \mathrm{C}$, the gas release rate increases continuously, releasing a large amount of gas. Fig. 3 shows that the release of $\mathrm{CS}_{2}$ and $\mathrm{H}_{2} \mathrm{~S}$ is mainly concentrated in the first 3 min, with the release of $\mathrm{C}_{2} \mathrm{~S}$ and $\mathrm{H}_{2} \mathrm{~S}$ being 20.84 and $339.42 \mu \mathrm{g} / \mathrm{g}$, respectively, accounting for $93.2 \%$ and $93.4 \%$ of the total release. At this temperature for $\mathrm{CS}_{2}$, most $\mathrm{CH}_{4}$ produced by sludge pyrolysis reacts with $\mathrm{FeS}$ within $3 \mathrm{~min}$ and is consumed completely. For $\mathrm{H}_{2} \mathrm{~S}$, this is mainly due to the complete decomposition of most sulfur-containing organic acids. When the time is $2 \mathrm{~min}$, the $\mathrm{SO}_{2}$ release amount of $\mathrm{SO}_{2}$ released can reach $77.58 \mu \mathrm{g} / \mathrm{g}$, accounting for $92.4 \%$ of the total release, and then, the release rate rapidly decreases. This is because the sulfur-containing aliphatic group that can be decomposed in the sludge decomposes almost completely in $2 \mathrm{~min}$ at a temperature of $250^{\circ} \mathrm{C}$.

\subsection{CBP inhibits the release of sulfur gas}

Fig. 4 shows the variation of $\mathrm{H}_{2} \mathrm{~S}$ concentration during sludge drying with different CBP contents. The concentration of $\mathrm{H}_{2} \mathrm{~S}$ in the waste gas decreases significantly as $\mathrm{CBP}$ content increases. The concentration of $\mathrm{H}_{2} \mathrm{~S}$ increases with increasing temperature. The concentration of $\mathrm{H}_{2} \mathrm{~S}$ in the gas produced by the drying of pure sludge is $1038.62 \mathrm{mg} / \mathrm{m}^{3}$ at a temperature of $250^{\circ} \mathrm{C}$. When $10 \mathrm{wt} \% \mathrm{CBP}$ 
was added, the concentration of $\mathrm{H}_{2} \mathrm{~S}$ was reduced by $85 \%$; when the mass ratio of CBP to sludge was 1:5, the concentration of $\mathrm{H}_{2} \mathrm{~S}$ was only $59.81 \mathrm{mg} / \mathrm{m}^{3}$, which was $94 \%$ lower than that of dry sludge gas $\left(1038.62 \mathrm{mg} / \mathrm{m}^{3}\right)$ without CBP. Additionally, the mixed $\mathrm{CBP}$ and $\mathrm{pH}$ value of sludge were determined. When the amount of CBP was $10 \mathrm{wt} \%(\mathrm{CBP}$ :sludge $=1: 10$ ), the $\mathrm{pH}$ value of sludge increased from 6.5 to 11.1, whereas the concentration of $\mathrm{H}_{2} \mathrm{~S}$ in the tail gas decreased significantly decreased. The concentration of $\mathrm{H}_{2} \mathrm{~S}$ was $50.57 \mathrm{mg} / \mathrm{m}^{3}$ when dried at $200^{\circ} \mathrm{C}$.

Previous studies have shown that heat decomposed aliphatic sulfur and aromatic sulfur in sludge, and then, $\mathrm{C}-\mathrm{S}$ bonds were broken, producing sulfur-containing gas (Zhang et al.,2017a). Additionally, alkali can inhibit the release of sulfur-containing gas during sludge drying, and the stronger the alkalinity, the better the effect (Cheng et al., 2017; Liu et al.,2014b ). This is because, at a certain temperature, alkali can promote the oxidation of aliphatic sulfur and aromatic sulfur to sulfoxide and sulfone in sludge, respectively, and eventually sulfonic acid may be produced (Cheng et al., 2017;Tang et al., 2017; Liu et al., 2012). Moreover, sulfoxide and sulfone almost do not produce sulfur-containing gas during the drying process, and their properties are more stable. Fig. 5 shows that $R-S-R$ uniformly represents aliphatic sulfur and aromatic sulfur. Sulfoxide, sulfone, and sulfonate can be labeled as $\mathrm{R}-\mathrm{SO}-\mathrm{R}, \mathrm{R}-\mathrm{SO}_{2}-\mathrm{R}$, and $\mathrm{R}-\mathrm{SO}_{3}-\mathrm{R}$, respectively. Because of the low bond dissociation energy of the $\mathrm{C}-\mathrm{S}$ bond in $\mathrm{R}-\mathrm{S}-\mathrm{R}$ compounds, the $\mathrm{C}-\mathrm{S}$ bond is easy to cleave at low temperatures to form sh-radical and then form $\mathrm{H}_{2} \mathrm{~S}$. Following the addition of alkali, a series of reactions, as shown in Fig. 5 , occur because of the action of $\mathrm{OH}^{-}$. Finally, hexavalent sulfur sulfonic acids are formed through nucleophilic addition, which greatly inhibits the release of $\mathrm{H}_{2} \mathrm{~S}$ and other gases. Some scholars have proposed that the active components of the conditioner added in the sludge can react with some free groups in the sludge to form precipitation, so that most of the sulfur elements are fixed in various solid compounds, and the relative ratio of sulfates and inorganic sulfides is rapidly increased sharply (Lens et al., 1998). Thus, the addition of CaO can cause a series of complex physical and chemical reactions of sulfur-containing substances in sludge, forming chelates with high stability and nonpolar calcium salts.

Additionally, alkalinity inhibits the growth of sulfate-reducing bacteria (SRB). SRB are anaerobic bacteria that can reduce elemental sulfur or sulfate to $\mathrm{H}_{2} \mathrm{~S}$ and other sulfur-containing gases. Thus, SRB activity is crucial for sulfate, sulfite, and organic sulfide in sludge to produce sulfur-containing gas (Dias et al., 2008 ). Weng et al. (2015) found that the optimal PH value for SRB growth is 7.0. Hence, the release of $\mathrm{H}_{2} \mathrm{~S}$ and $\mathrm{SO}_{2}$ can be inhibited by controlling the $\mathrm{pH}$ value of the sludge drying process and inhibiting the growth of SRB. To conclude, the addition of calcium-based ultrafine powders, on one hand, uses the strong oxidizing hydroxyl group to change the proportion of all types of organic sulfur in the sludge; on the other hand, it provides an alkaline environment and changes its internal biochemical conditions, thereby inhibiting the release of sulfur-containing gases.

\subsection{Absorption and adsorption of sulfur-containing gas by CBP}


Some characteristic gases collected in the airbag are shown in Tables 2 and 3 . Tables 2 and 3 show that a large number of alkanes, alkenes, alkynes, $\mathrm{CH}$ compounds, alkanes, and alkanols are produced when the sludge is decomposed at $300^{\circ} \mathrm{C}$. According to the chemical composition of gases in Table 3 , the sludge is decomposed without any treatment to produce various amino acids, organic compounds containing nitrogen and sulfur, and various sulfur-containing gases, such as $\mathrm{H}_{2} \mathrm{~S}, \mathrm{CS}_{2}$, and $\mathrm{COS}$.

Comparing the gas composition in Table 3 , there are almost no sulfur-containing organic compounds and sulfur-containing gases. After CBP adsorption, the types of gas collected in the airbag did not significantly change much, but the substances containing $S$ and $\mathrm{N}$ in Table 3 were reduced compared with those in Table 3, indicating that the adsorption of sulfur-containing gas in sludge using calciumbased ultrafine powder was very obvious, which helped control the emission of odor gas. The odor of sludge particles is obvious, but when the particles are completely coated by CBP, the odor is hardly emitted. This is because the odor is covered by a large amount of powder on the surface of the sludge particles, preventing it from passing through the surface fly ash layer.

Calcium-based desulfurizers commonly used in the market now include $\mathrm{CaO}, \mathrm{Ca}(\mathrm{OH})_{2}$, and $\mathrm{CaCO}_{3}$ (Zhang et al., 2017b), and the main component of CBP is $\mathrm{CaO}$, which can absorb sulfur gases such as $\mathrm{H}_{2} \mathrm{~S}$ and $\mathrm{SO}_{2}$. Second, $\mathrm{CaO}$ reacts with $\mathrm{SO}_{2}$ to form $\mathrm{CaSO}_{4}$ to realize desulfurization and sulfur fixation . The chemical reactions that occur are as follows:

\begin{tabular}{ll}
$\mathrm{SO}_{2}+\mathrm{CaO} \rightarrow \mathrm{Ca} \mathrm{SO}_{3}$ & $\nabla 1-3 \rrbracket$ \\
\hline $\mathrm{SO}_{2}+\mathrm{H}_{2} \mathrm{O} \rightarrow \mathrm{H}_{2} \mathrm{SO}_{3}$ & $\nabla 1-4 \rrbracket$ \\
\hline $\mathrm{CaO}+\mathrm{H}_{2} \mathrm{SO}_{3} \rightarrow \mathrm{CaSO}_{3}+\mathrm{H}_{2} \mathrm{O}$ & $(1-5)$ \\
$\mathrm{CaSO}_{3}+1 / 2 \mathrm{O}_{2} \rightarrow \mathrm{CaSO}_{4}$ & $(1-6)$
\end{tabular}

Because of the evaporation of aliphatic compounds in the process of sludge drying at $200^{\circ} \mathrm{C}-450^{\circ} \mathrm{C}$, water in the sludge drying process is not easily lost. The produced $\mathrm{H}_{2} \mathrm{~S}$ can be partially ionized in the presence of water, and $\mathrm{H}^{+}$and $\mathrm{HS}^{-}$can be generated by one-step ionization, and a small amount of $\mathrm{HS}^{-}$ can be ionized in two steps to form $\mathrm{S}^{2-}$; with $\mathrm{CaO}$, the amount of $\mathrm{H}_{2} \mathrm{~S}$ can be ionized to form $\mathrm{S}^{2-}$, and by increasing its content, it reacts with water to release heat and form $\mathrm{Ca}(\mathrm{OH})_{2}$. The alkalinity in the system increases gradually, neutralizing more $\mathrm{H}^{+}$, thus promoting the ionization of $\mathrm{H}_{2} \mathrm{~S}$ and producing more $\mathrm{S}^{2-}$, which can react with $\mathrm{CaO}$ to produce $\mathrm{CaS}$ or react with hydrated $\mathrm{Ca}(\mathrm{OH})_{2}$ to form $\mathrm{CaS}$; $\mathrm{SO}_{2}$ produced from organic sulfur decomposition will also react with $\mathrm{Ca}(\mathrm{OH})_{2}$ to form $\mathrm{CaSO}_{3}$, and $\mathrm{CaSO}_{4}$ is more stable under oxidation conditions (Karatepe et al., 1998). Other experimental results (Liu et al., 2012)also showed that when the sludge was dewatered with $\mathrm{CaO}$ as a conditioning agent, alkaline $\mathrm{CaO}$ promoted the conversion of most $\mathrm{H}_{2} \mathrm{~S}$ and $\mathrm{SO}_{2}$ to $\mathrm{CaS}$ and $\mathrm{CaSO}_{4}$, resulting in a rapid increase in the relative ratio of sulfate to inorganic sulfide. In particular, the addition of CBP, on one hand, produces sludge in an alkaline environment, and the acid-free $\mathrm{H}_{2} \mathrm{~S}$ and $\mathrm{SO}_{2}$ molecules can react with $\mathrm{CaO}$ and $\mathrm{Ca}(\mathrm{OH})_{2}$ to form stable calcium salt, thus reducing the inorganic sulfur release process in the subsequent drying process; 
on the other hand, the alkaline calcium materials can absorb the release of sulfur-containing organic matter during the sludge drying process. Acid gases such as $\mathrm{H}_{2} \mathrm{~S}$ and $\mathrm{SO}_{2}$ can further reduce the sulfur released during the drying process.

Generally, the chemical process of absorption must be accompanied by the adsorption process. Calciumbased superfine powder can absorb and adsorb sulfur-containing gas at the same time. The main components of $\mathrm{CBP}$ powder are $\mathrm{SiO}_{2}$ and $\mathrm{CaCO}_{3}$, and it also contains a lot of amorphous $\mathrm{SiO}_{2}$ and $\mathrm{Al}_{2} \mathrm{O}_{3}$, which can be regarded as a type of pozzolanic ash. In the presence of water at normal temperature, properly crushed pozzolan can react with an alkali metal and alkaline earth metal hydrate.

These newly formed hydrated aluminosilicates are usually incomplete crystals, mostly fibrous, with large specific surface area and high-water holding capacity (Deng and Su, 2014). The results show that the reaction of (2-1)-(2-4) changes the surface structure of the powder, increases the specific surface area, improves the pore structure, and improves the pore structure and the gas adsorption effect, whereas the high-water holding capacity increases the humidity of the powder particles and accelerates the reaction on the surface (Sanders et al., 1995). CBP powder may also play a catalytic role, especially the high content of silicon, iron, magnesium, and aluminum, and some trace elements can also promote the absorption of gas (Gong et al., 2019). Additionally, a large number of studies have shown that the potentially active powder and $\mathrm{CaO}$ can be digested to form calcium silicate hydrates and form loose porous structure, thus greatly improving the adsorption of sulfur-containing gas.

$$
\begin{aligned}
& \mathrm{Ca}(\mathrm{OH})_{2}+\mathrm{SiO}_{2}+\mathrm{H}_{2} \mathrm{O} \rightarrow(\mathrm{CaO})_{x}\left(\mathrm{SiO}_{2}\right) \mathrm{y}\left(\mathrm{H}_{2} \mathrm{O}\right)_{\mathrm{z}} \\
& \mathrm{Ca}(\mathrm{OH})_{2}+\mathrm{A}_{2} \mathrm{O}_{3}+\mathrm{H}_{2} \mathrm{O} \rightarrow(\mathrm{CaO})_{x}\left(\mathrm{~A}_{2} \mathrm{O}_{3}\right)_{\mathrm{y}}\left(\mathrm{H}_{2} \mathrm{O}\right)_{\mathrm{z}} \\
& \mathrm{Ca}(\mathrm{OH})_{2}+\mathrm{A}_{2} \mathrm{O}_{3}+\mathrm{SiO}_{2}+\mathrm{H}_{2} \mathrm{O} \rightarrow(\mathrm{CaO})_{x}\left(\mathrm{~A}_{2} \mathrm{O}_{3}\right)_{y}\left(\mathrm{SiO}_{2}\right) \mathrm{z}\left(\mathrm{H}_{2} \mathrm{O}\right)_{\mathrm{w}} \\
& \mathrm{Ca}(\mathrm{OH})_{2}+\mathrm{A}_{2} \mathrm{O}_{3}+\mathrm{SO}_{3}+\mathrm{H}_{2} \mathrm{O} \rightarrow(\mathrm{CaO})_{x}\left(\mathrm{~A}_{2} \mathrm{O}_{3}\right)_{y}\left(\mathrm{CaSO}_{3}\right) \mathrm{z}\left(\mathrm{H}_{2} \mathrm{O}\right)_{\mathrm{w}}
\end{aligned}
$$

Table 3. Representative gas released by sludge at $300^{\circ} \mathrm{C}$ 


\begin{tabular}{|c|c|c|c|c|c|}
\hline Number & Type & $\begin{array}{l}\text { Appearance } \\
\text { time (min) }\end{array}$ & Name & $\begin{array}{l}\text { Chemical } \\
\text { formula }\end{array}$ & $\begin{array}{l}\text { Molecular } \\
\text { weight }\end{array}$ \\
\hline \multirow[t]{5}{*}{1} & \multirow{5}{*}{$\begin{array}{l}\text { Hydrocarbon } \\
\text { organic } \\
\text { matter }\end{array}$} & 0.392 & Ketene & $\mathrm{C}_{2} \mathrm{H}_{2} \mathrm{O}$ & 42.011 \\
\hline & & 0.815 & Oxalic acid & $\mathrm{C}_{2} \mathrm{H}_{2} \mathrm{O}_{4}$ & 89.995 \\
\hline & & 2.258 & Methanol-D4 & $\mathrm{CD}_{4} \mathrm{O}$ & 36.051 \\
\hline & & 11.729 & $(\mathrm{R}, \mathrm{R})$-Tartaric acid & $\mathrm{C}_{4} \mathrm{H}_{6} \mathrm{O}_{6}$ & 150.016 \\
\hline & & 11.729 & $\begin{array}{l}\text { Butanedioic acid, } 2,3- \\
\text { dihydroxy-, }\left[\mathrm{S}-\left(\mathrm{R}^{\star}, \mathrm{R}^{\star}\right)\right]-\end{array}$ & $\mathrm{C}_{4} \mathrm{H}_{6} \mathrm{O}_{6}$ & 150.016 \\
\hline \multirow[t]{9}{*}{2} & \multirow[t]{9}{*}{$\begin{array}{l}\text { Nitrogenous } \\
\text { compounds }\end{array}$} & 0.620 & Diazirine & $\mathrm{CH}_{2} \mathrm{~N}_{2}$ & 42.022 \\
\hline & & 0.620 & $\begin{array}{l}\text { Pyrazine, methoxy-, 1- } \\
\text { oxide }\end{array}$ & $\mathrm{C}_{5} \mathrm{H}_{6} \mathrm{~N}_{2} \mathrm{O}_{2}$ & 126.043 \\
\hline & & 0.815 & Dimethylamine & $\mathrm{C}_{2} \mathrm{H}_{7} \mathrm{~N}$ & 45.058 \\
\hline & & 0.815 & Epinephrine & $\mathrm{C}_{9} \mathrm{H}_{13} \mathrm{NO}_{3}$ & 183.09 \\
\hline & & 0.815 & 2-Hexanamine, 4-methyl- & $\mathrm{C}_{7} \mathrm{H}_{17} \mathrm{~N}$ & 115.136 \\
\hline & & 0.815 & $\begin{array}{l}\text { 2-Propanamine, 1- } \\
\text { methoxy- }\end{array}$ & $\mathrm{C}_{4} \mathrm{H}_{11} \mathrm{NO}$ & 89.084 \\
\hline & & 3.798 & 2-Amino-1,3-propanediol & $\mathrm{C}_{3} \mathrm{H}_{9} \mathrm{NO}_{2}$ & 91.063 \\
\hline & & 6.214 & Methyl isocyanide & $\mathrm{C}_{2} \mathrm{H}_{3} \mathrm{~N}$ & 41.027 \\
\hline & & 10.133 & Butane, 1-isocyano- & $\mathrm{C}_{5} \mathrm{H}_{9} \mathrm{~N}$ & 83.073 \\
\hline \multirow[t]{8}{*}{3} & \multirow{8}{*}{$\begin{array}{l}\text { Sulfur- } \\
\text { containing } \\
\text { substances }\end{array}$} & 0.620 & 2-Pyrrolidinethione & $\mathrm{C}_{4} \mathrm{H}_{7} \mathrm{NS}$ & 101.03 \\
\hline & & 2.258 & Hydrogen sulfide & $\mathrm{H}_{2} \mathrm{~S}$ & 33.988 \\
\hline & & 3.798 & Carbonyl sulfide & $\cos$ & 59.967 \\
\hline & & 3.798 & $\begin{array}{l}\text { Ethanone, 1-(5-methylfur- } \\
\text { 2-yl)-, Thiosemicarbazone }\end{array}$ & $\mathrm{C}_{8} \mathrm{H}_{11} \mathrm{~N}_{3} \mathrm{OS}$ & 197.062 \\
\hline & & 11.729 & Carbon disulfide & $\mathrm{CS}_{2}$ & 42.011 \\
\hline & & 11.729 & $\begin{array}{l}\text { 4,4'- } \\
\text { Diisothiocyanatostilbene- } \\
\text { 2,2'-disulfonic acid }\end{array}$ & $\mathrm{C}_{16} \mathrm{H}_{10} \mathrm{~N}_{2} \mathrm{O}_{6} \mathrm{~S}_{4}$ & 453.942 \\
\hline & & 11.729 & Thiourea & $\mathrm{CH}_{4} \mathrm{~N}_{2} \mathrm{~S}$ & 76.01 \\
\hline & & 11.729 & Monoethyl & $\mathrm{C}_{3} \mathrm{H}_{6} \mathrm{~S}_{3}$ & 137.963 \\
\hline
\end{tabular}




\begin{tabular}{|clllr|}
\hline 11.729 & $\begin{array}{l}\text { Mono-sec-butyl } \\
\text { carbonotrithioate }\end{array}$ & $\mathrm{C}_{5} \mathrm{H}_{10} \mathrm{~S}_{3}$ & 165.994 \\
\hline 11.729 & Mecysteine & $\mathrm{C}_{4} \mathrm{H}_{10} \mathrm{ClNO}_{2} \mathrm{~S}$ & 151.979 \\
\hline 22.729 & $\begin{array}{l}\text { Monoisopropyl } \\
\text { carbonotrithioate }\end{array}$ & $\mathrm{C}_{4} \mathrm{H}_{8} \mathrm{~S}_{3}$ & 151.979 \\
\hline
\end{tabular}

Table 3. Representative gas components collected by sludge $300^{\circ} \mathrm{C}$ heating sampling bag 


\begin{tabular}{|c|c|c|c|c|c|}
\hline Number & Type & $\begin{array}{l}\text { Appearance } \\
\text { time (min) }\end{array}$ & Name & $\begin{array}{l}\text { Chemical } \\
\text { formula }\end{array}$ & $\begin{array}{l}\text { Molecular } \\
\text { weight }\end{array}$ \\
\hline \multirow[t]{3}{*}{1} & \multirow{3}{*}{$\begin{array}{l}\text { Hydrocarbon } \\
\text { organic } \\
\text { matter }\end{array}$} & 22.153 & Cyclobutanol & $\mathrm{C}_{4} \mathrm{H}_{8} \mathrm{O}$ & 72.058 \\
\hline & & 22.379 & Phthalan & $\mathrm{C}_{8} \mathrm{H}_{8} \mathrm{O}$ & 120.058 \\
\hline & & & Benzene, (butoxymethyl)- & $\mathrm{C}_{11} \mathrm{H}_{16} \mathrm{O}$ & 164.12 \\
\hline \multirow[t]{8}{*}{2} & \multirow{8}{*}{$\begin{array}{l}\text { Nitrogen } \\
\text { oxide organic } \\
\text { matter }\end{array}$} & 22.379 & 2-Propanamine, 1-methoxy- & $\mathrm{C}_{4} \mathrm{H}_{11} \mathrm{NO}$ & 89.084 \\
\hline & & 22.153 & I-Guanidinosuccinimide & $\mathrm{C}_{5} \mathrm{H}_{7} \mathrm{~N}_{3} \mathrm{O}_{2}$ & 141.054 \\
\hline & & & $\begin{array}{l}\text { I-Alanyl-I-alanyl-I-alanine } \\
\text { methyl ester }\end{array}$ & $\mathrm{C}_{10} \mathrm{H}_{19} \mathrm{~N}_{3} \mathrm{O}_{4}$ & 245.138 \\
\hline & & & dl-Alanine ethyl ester & $\mathrm{C}_{5} \mathrm{H}_{11} \mathrm{NO}_{2}$ & 117.079 \\
\hline & & & $\begin{array}{l}\text { Acetic acid, hydroxy[(1-oxo- } \\
\text { 2-propenyl) amino]- }\end{array}$ & $\mathrm{C}_{5} \mathrm{H}_{7} \mathrm{NO}_{4}$ & 145.038 \\
\hline & & & L-Alanine, methyl ester & $\mathrm{C}_{4} \mathrm{H}_{9} \mathrm{NO}_{2}$ & 103.063 \\
\hline & & & Cathinone & $\mathrm{C}_{9} \mathrm{H}_{11} \mathrm{NO}$ & 149.084 \\
\hline & & & $\begin{array}{l}\text { Benzenemethanol, 3- } \\
\text { hydroxy-.alpha.- } \\
\text { [(methylamino) methyl]-, (R)- }\end{array}$ & $\mathrm{C}_{9} \mathrm{H}_{13} \mathrm{NO}_{2}$ & 167.095 \\
\hline \multirow[t]{8}{*}{3} & \multirow[t]{8}{*}{$\begin{array}{l}\text { Nitrogenous } \\
\text { compounds }\end{array}$} & 22.153 & n-Hexylmethylamine & $\mathrm{C}_{7} \mathrm{H}_{17} \mathrm{~N}$ & 115.136 \\
\hline & & & Amphetamine-3-methyl & $\mathrm{C}_{10} \mathrm{H}_{15} \mathrm{~N}$ & 149.12 \\
\hline & & & N-Dodecylmethylamine & $\mathrm{C}_{13} \mathrm{H}_{29} \mathrm{~N}$ & 199.23 \\
\hline & & & 2-Heptanamine, 5-methyl- & $\mathrm{C}_{8} \mathrm{H}_{19} \mathrm{~N}$ & 129.152 \\
\hline & & & $\begin{array}{l}\text { 1-Octadecanamine, } \mathrm{N} \text { - } \\
\text { methyl- }\end{array}$ & $\mathrm{C}_{19} \mathrm{H}_{41} \mathrm{~N}$ & 283.324 \\
\hline & & 22.397 & $\begin{array}{l}\text { 1-Propanamine, N,2- } \\
\text { dimethyl- }\end{array}$ & $\mathrm{C}_{5} \mathrm{H}_{13} \mathrm{~N}$ & 87.105 \\
\hline & & & sec-Butylamine & $\mathrm{C}_{4} \mathrm{H}_{11} \mathrm{~N}$ & 73.089 \\
\hline & & & $\begin{array}{l}\text { Benzeneethanamine, N- } \\
\text { methyl- }\end{array}$ & $\mathrm{C}_{9} \mathrm{H}_{13} \mathrm{~N}$ & 135.105 \\
\hline
\end{tabular}

\section{Conclusion}


Experimental results showed that as the sludge drying temperature increased, more $\mathrm{CS}_{2}, \mathrm{H}_{2} \mathrm{~S}$, and $\mathrm{SO}_{2}$ were released from the sludge, and the release of $\mathrm{H}_{2} \mathrm{~S}$ and $\mathrm{SO}_{2}$ rapidly increased at $200^{\circ} \mathrm{C}$ and $250^{\circ} \mathrm{C}$, respectively, indicating that the amount of gas released could be effectively reduced when the temperature was controlled below $250^{\circ} \mathrm{C}$. By increasing the sludge drying time, the amount of $\mathrm{CS}_{2}, \mathrm{H}_{2} \mathrm{~S}$, and $\mathrm{SO}_{2}$ released from the sludge increased continuously, and the gas release rate increased first and then decreased. The amount of gas released began to increase significantly at $30 \mathrm{~s}$, and a large amount of gas was released within $3 \mathrm{~min}$, indicating that reducing the drying time can effectively decrease the amount of gas released.

Furthermore, the experimental results show that when the amount of calcium-based ultrafine powder added reached $20 \%$ of the original sludge mass fraction, the concentration of sulfur gas released was only $59.81 \mathrm{mg} / \mathrm{m}^{3}$, which was $94 \%$ lower than that of the dry sludge gas without CBP. This is because the CBP provides an alkaline environment, which promotes the conversion of more organic compounds in the sludge into more stable sulfoxides and sulfoxides, and inhibits the growth of sulfuric acid-reducing bacteria, thereby inhibiting the release of $\mathrm{H}_{2} \mathrm{~S}$ and $\mathrm{SO}_{2}$. Additionally, the experiment showed that after adding CBP, the number and damage degree of harmful gases in the sludge drying process decreased. $\mathrm{H}_{2} \mathrm{~S}$ and $\mathrm{SO}_{2}$ molecules are neutralized by calcium-based ultrafine powder, forming stable calcium salts. Hence, using CBP and sludge to form a coating ball to inhibit and absorb the sludge dry sulfur odor is an effective way to control the emission of odor gases.

\section{Declarations}

\section{Acknowledgments}

The authors wish to express their thanks to the National water pollution control and scientific and technological special project of China (2010ZX07319-002) and the Natural Science Foundation of Shaanxi Province (Grant No. 2020SF-417) for the financial support of this research.

\section{Funding}

This work was supported by the National Water Pollution Control and Scientific and Technological Special Project of China (2010ZX07319-002) and the Natural Science Foundation of Shaanxi Province (Grant No. 2020SF-417).

\section{Conflicts of interest/Competing interests (include appropriate disclosures)}

We declare that we have no financial and personal relationships with other people or organizations that can inappropriately influence our work, there is no professional or other personal interest of any nature or kind in any product, service and/or company that could be construed as influencing the position presented in, or the review of, the manuscript entitled.

\section{Availability of data and material (data transparency)}


All data generated or analysed during this study are included in this published article (and its supplementary information files).

\section{Code availability (software application or custom code)}

Not applicable

\section{Authors' contributions}

Haihong Fan and Binbin Li contributed to the conception of the study;

Shuo Shang, Lin Li and Zhou Li performed the experiment;

Haihong Fan and Shuo Shang contributed significantly to analysis and manuscript preparation;

Shuo Shang performed the data analyses and wrote the manuscript;

Binbin Li helped perform the analysis with constructive discussions.

\section{Ethics approval (include appropriate approvals or waivers)}

Not applicable

\section{Consent to participate (include appropriate statements)}

The Author confirms :

that the work described has not been published before (except in the form ofan abstract or as part of published lecture review, or thesis);

that it is not under consideration for publication elsewhere

that its publication has been approved by all co-authors, if any;

that its publication has been approved (tacitly or explicitly) by the responsible authorities at the institution where the work is carried out.

\section{References}

1. Cheng S, Qiao Y, Huang J, Cao L, Yang H, Liu H, ... Xu M (2017) Effect of alkali addition on sulfur transformation during low temperature pyrolysis of sewage sludge. Proceedings of the Combustion Institute, 36(2), 2253-2261.https://doi.org/10.1016/j.proci.2016.06.124

2. Dewil R, Baeyens J, Roels J, Steene BVD (2008) Distribution of sulphur compounds in sewage sludge treatment. Environ Eng Sci 25(6):879-886. https://doi.org/10.1089/ees.2007.0143 
3. Dias M, Salvado JC, Monperrus M, Caumette P, Amouroux D, Duran R, Guyoneaud R (2008) Characterization of Desulfomicrobium salsuginis sp. nov. and Desulfomicrobium aestuarii sp. nov., two new sulfate-reducing bacteria isolated from the Adour estuary (French Atlantic coast) with specific mercury methylation potentials. Syst Appl Microbiol 31(1):30-37.

https://doi.org/10.1016/j.syapm.2007.09.002

4. Donner E, Howard DL, Jonge MDD, Paterson D, Cheah MH, Naidu R, Lombi E (2011) X-ray absorption and micro X-ray fluorescence spectroscopy investigation of copper and zinc speciation in biosolids. Environ Sci Technol 45(17):7249-7257. https://doi.org/10.1021/es201710z

5. Du W, Parker W (2013) Characterization of sulfur in raw and anaerobically digested municipal wastewater treatment sludges. Water environment research 85(2):124-132. https://doi.org/10.2175/106143012X13407275694671

6. Deng W, Su Y (2014) Experimental study on agitated drying characteristics of sewage sludge under the effects of different additive agents. J Environ Sci 26(7):1523-1529. https://doi.org/10.1016/j.jes.2014.05.019

7. Gong Z, Wang Z, Wang Z, Fang P, Meng F (2019) Study on the migration characteristics of nitrogen and sulfur during co-combustion of oil sludge char and microalgae residue. Fuel 238:1-9. https://doi.org/10.1016/j.fuel.2018.10.087

8. Huang R, Tang Y, Luo L (2021) Thermochemistry of sulfur during pyrolysis and hydrothermal carbonization of sewage sludges. Waste Manag 121:276-285. https://doi.org/10.1016/j.wasman.2020.12.004

9. Karatepe N, Mericboyu AE, Küçükbayrak S (1998) Effect of hydration conditions on the physical properties of fly ash-Ca (OH) 2 sorbents. Energy Sources 20(6):505-511. https://doi.org/10.1080/00908319808970075

10. Kelessidis A, Stasinakis AS (2012) Comparative study of the methods used for treatment and final disposal of sewage sludge in European countries. Waste management 32(6):1186-1195. https://doi.org/10.1016/j.wasman.2012.01.012

11. Lens PNL, Visser A, Janssen AJH, Pol LH, Lettinga G (1998) Biotechnological treatment of sulfaterich wastewaters. Crit Rev Environ Sci Technol 28(1):41-88.

https://doi.org/10.1080/10643389891254160

12. Lin RB, Shih SM (2003) Characterization of $\mathrm{Ca}(\mathrm{OH}) 2 /$ fly ash sorbents for flue gas desulfurization. Powder technology 131(2-3):212-222. https://doi.org/10.1016/S0032-5910(03)00003-2

13. Liu H, Luo GQ, Hu HY, Zhang Q, Yang JK, Yao H (2012) Emission characteristics of nitrogen-and sulfur-containing odorous compounds during different sewage sludge chemical conditioning processes. J Hazard Mater 235:298-306. https://doi.org/10.1016/j.jhazmat.2012.07.060

14. Lu S, Chen L, Huang Q, Yang L, Du C, Li X, Yan J (2014) Decomposition of ammonia and hydrogen sulfide in simulated sludge drying waste gas by a novel non-thermal plasma. Chemosphere 117:781-785. https://doi.org/10.1016/j.chemosphere.2014.10.036 
15. Luo L, Xu C, Ma Y, Zheng L, Liu L, Lv J, Zhang S (2014) Sulfur speciation in an arable soil as affected by sample pretreatments and sewage sludge application. Soil Sci Soc Am J 78(5):1615-1623. https://doi.org/10.2136/sssaj2013.11.0506

16. Lin H, Ye C, Lv L, Zheng CR, Zhang S, Zheng L, ... Yu X (2014) Characterization of extracellular polymeric substances in the biofilms of typical bacteria by the sulfur K-edge XANES spectroscopy. J Environ Sci 26(8):1763-1768. https://doi.org/10.1016/j.jes.2014.06.017

17. Liu H, Zhang Q, Hu H, Xiao R, Li A, Qiao Y, ... Naruse I (2014) Dual role of conditioner CaO in product distributions and sulfur transformation during sewage sludge pyrolysis. Fuel 134:514-520. https://doi.org/10.1016/j.fuel.2014.06.020

18. Liu H, Liu P, Hu H, Zhang Q, Wu Z, Yang J, Yao H (2014) Combined effects of Fenton peroxidation and $\mathrm{CaO}$ conditioning on sewage sludge thermal drying. Chemosphere 117:559-566. https://doi.org/10.1016/j.chemosphere.2014.09.038

19. Liu S, Wei M, Qiao Y, Yang Z, Gui B, Yu Y, Xu M (2015) Release of organic sulfur as sulfur-containing gases during low temperature pyrolysis of sewage sludge. Proceedings of the Combustion Institute, 35(3), 2767-2775.https://doi.org/10.1016/j.proci.2014.06.055

20. Liu Y, Ran C, Siddiqui AR, Siyal AA, Song Y, Dai J, ... Zhang T (2020) Characterization and analysis of sludge char prepared from bench-scale fluidized bed pyrolysis of sewage sludge. Energy 200:117398. https://doi.org/10.1016/j.energy.2020.117398

21. Ros A, Montes-Moran MA, Fuente E, Nevskaia DM, Martin MJ (2006) Dried sludges and sludge-based chars for H2S removal at low temperature: influence of sewage sludge characteristics. Environ Sci Technol 40(1):302-309. https://doi.org/10.1021/es050996j

22. Sanders JF, Keener TC, Wang J (1995) Heated fly ash/hydrated lime slurries for SO2 removal in spray dryer absorbers. Ind Eng Chem Res 34(1):302-307. https://doi.org/10.1021/ie00040a032

23. Svanström M, Fröling M, Olofsson M, Lundin M (2005) Environmental assessment of supercritical water oxidation and other sewage sludge handling options. Waste management research 23(4):356366. https://doi.org/10.1177/0734242X05054324

24. Thipkhunthod P, Meeyoo V, Rangsunvigit P, Rirksomboon T (2007) Describing sewage sludge pyrolysis kinetics by a combination of biomass fractions decomposition. J Anal Appl Pyrol 79(12):78-85. https://doi.org/10.1016/j.jaap.2006.10.005

25. Tang S, Tian S, Zheng C, Zhang Z (2017) Effect of calcium hydroxide on the pyrolysis behavior of sewage sludge: reaction characteristics and kinetics. Energy Fuels 31(5):5079-5087. https://doi.org/10.1021/acs.energyfuels.6b03256

26. Udayanga WC, Veksha A, Giannis A, Lisak G, Lim TT (2019) Effects of sewage sludge organic and inorganic constituents on the properties of pyrolysis products. Energy Conv Manag 196:1410-1419. https://doi.org/10.1016/j.enconman.2019.06.025

27. Weng H, Dai Z, Ji Z, Gao C, Liu C (2015) Release and control of hydrogen sulfide during sludge thermal drying. J Hazard Mater 296:61-67. https://doi.org/10.1016/j.jhazmat.2015.04.037 
28. Yin Q, Liu M, Ren H (2019) Biochar produced from the co-pyrolysis of sewage sludge and walnut shell for ammonium and phosphate adsorption from water. Journal of environmental management 249:109410. https://doi.org/10.1016/j.jenvman.2019.109410

29. Zhang L, De Schryver P, De Gusseme B, De Muynck W, Boon N, Verstraete W (2008) Chemical and biological technologies for hydrogen sulfide emission control in sewer systems: a review. Water Res 42(1-2):1-12. https://doi.org/10.1016/j.watres.2007.07.013

30. Zhang J, Zuo W, Tian Y, Chen L, Yin L, Zhang J (2017) Sulfur transformation during microwave and conventional pyrolysis of sewage sludge. Environ Sci Technol 51(1):709-717. https://doi.org/10.1021/acs.est.6b03784

31. Zhang J, Tian Y, Yin L, Zuo W, Gong Z, Zhang J (2017) Investigation on the removal of H 2 S from microwave pyrolysis of sewage sludge by an integrated two-stage system. Environ Sci Pollut Res 24(24):19920-19926. https://doi.org/10.1007/s11356-017-9637-6

\section{Figures}

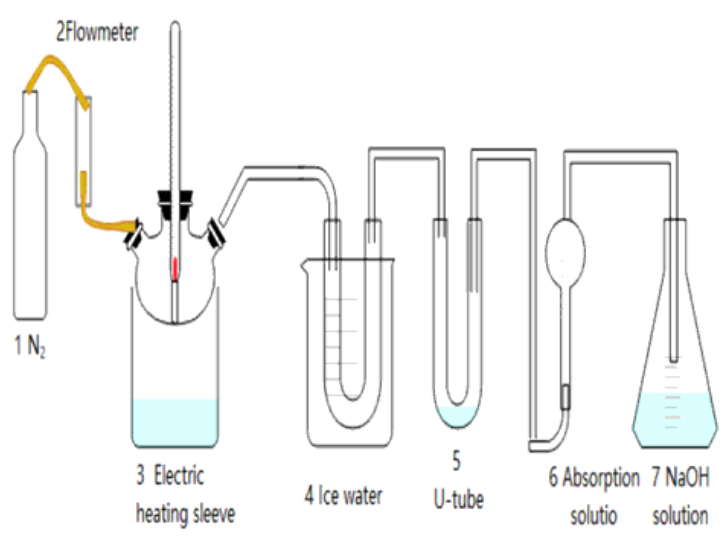

a

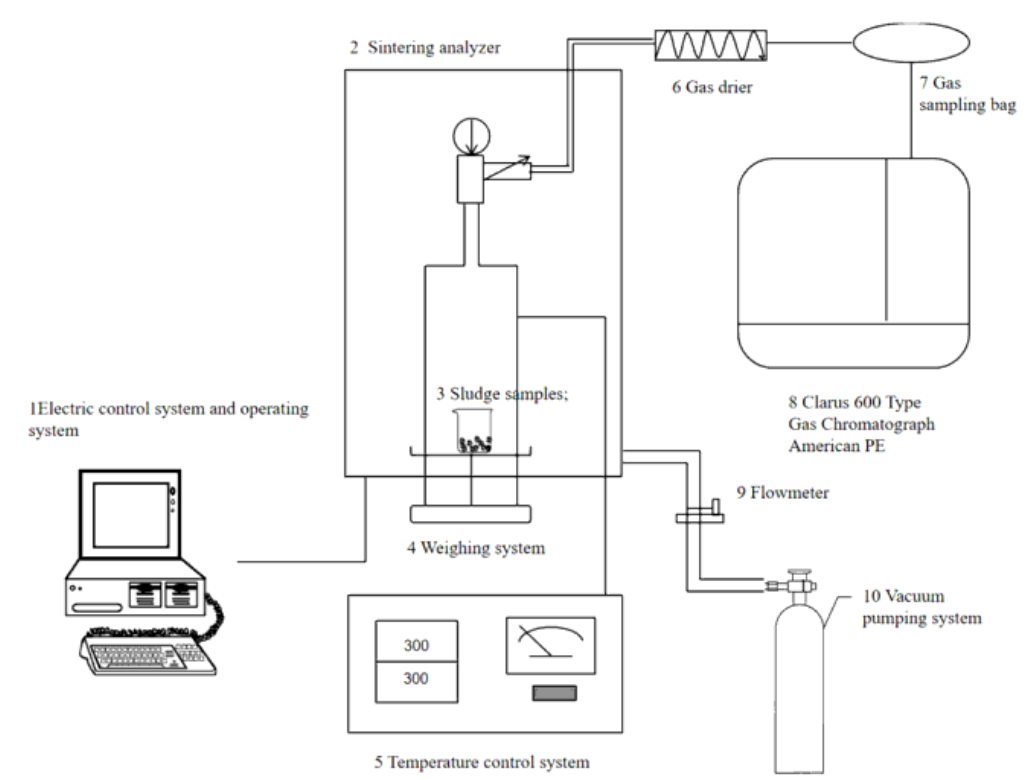

b

\section{Figure 1}

(a) Gas absorption experiment device; (b) Experimental diagram of drying sludge system 


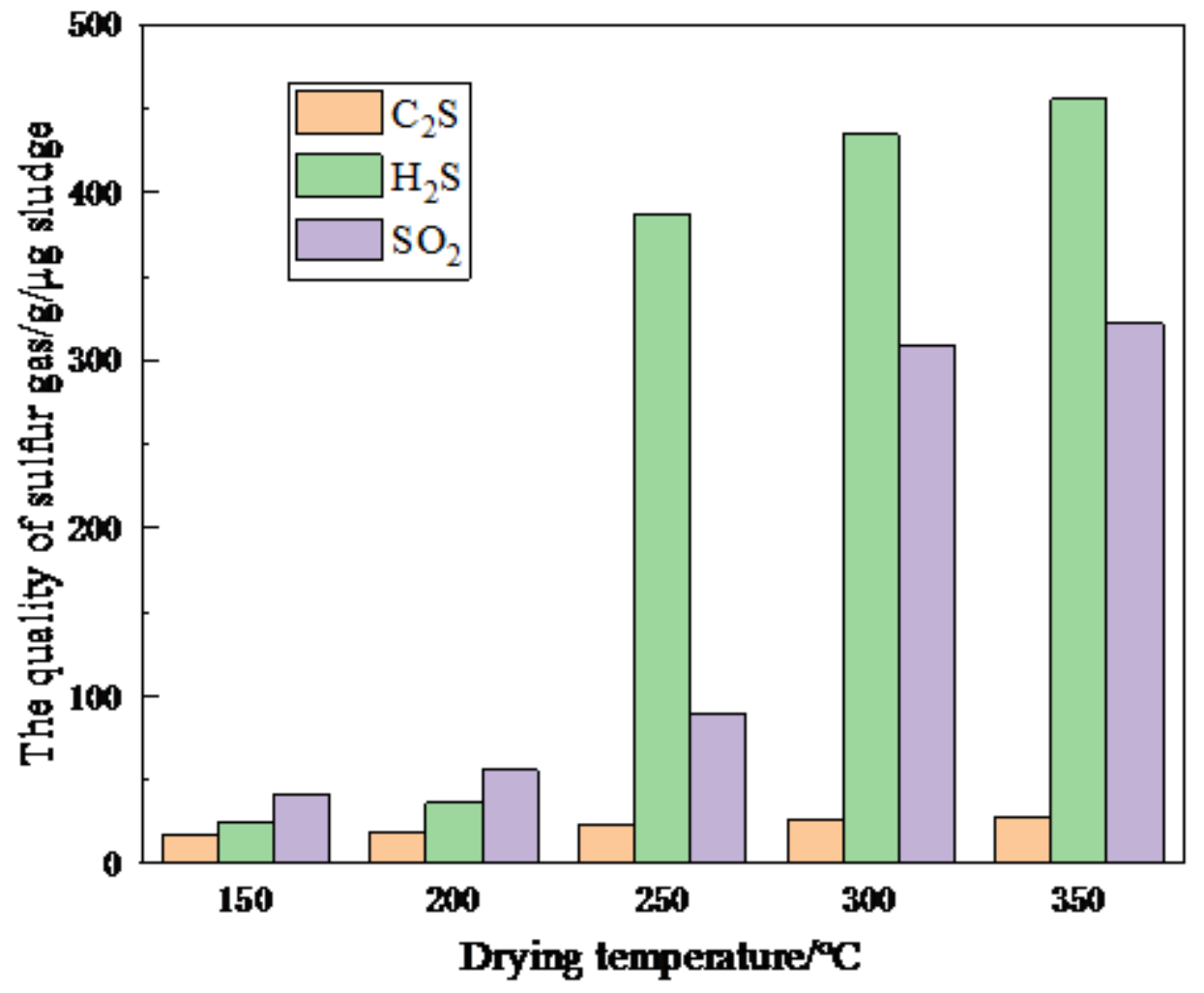

Figure 2

Influence of drying temperature on the amount of releasion of the gas released 


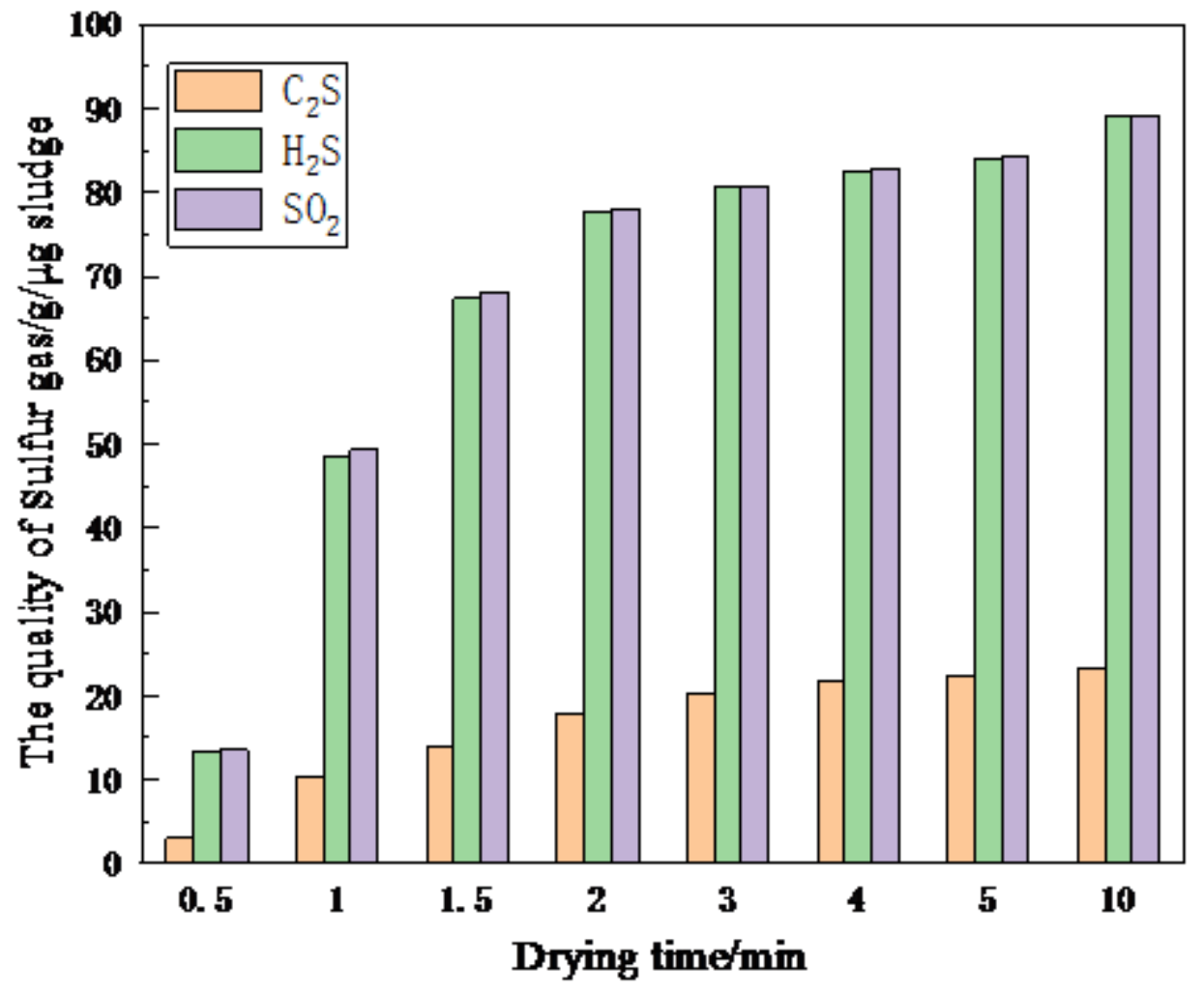

Figure 3

Influence of drying time on the amount of releasion of the gas released 


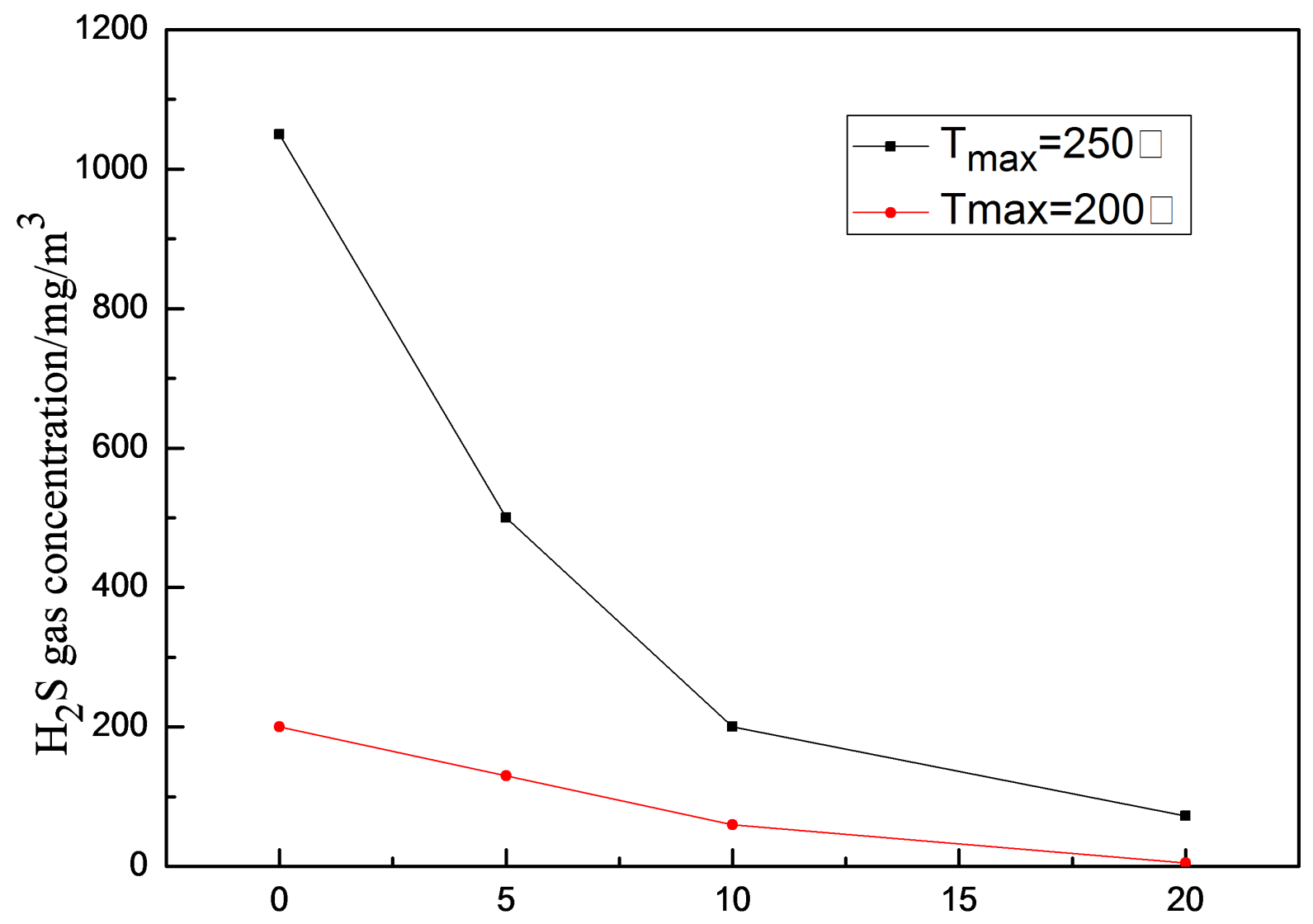

Figure 4

variation of $\mathrm{H} 2 \mathrm{~S}$ concentration in sludge drying process with different $\mathrm{CBP}$ content

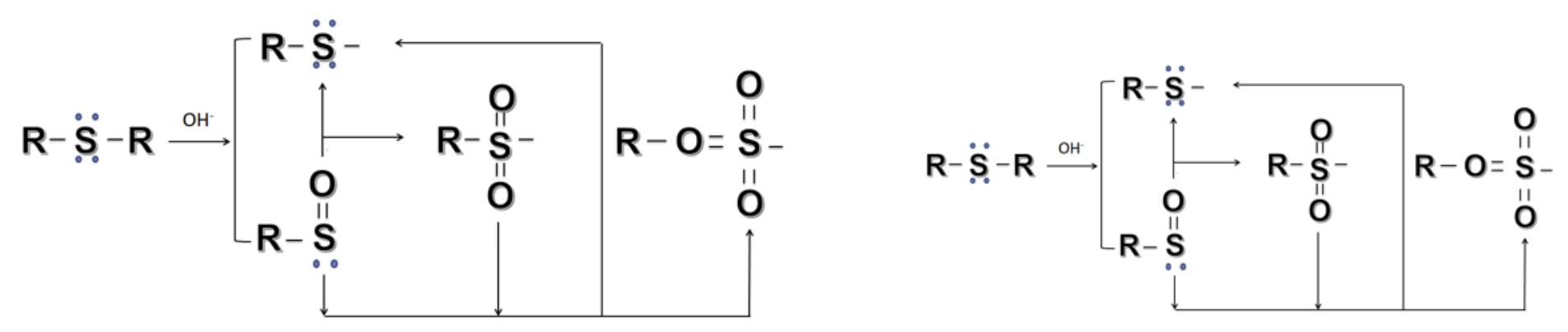

Figure 5

Diagram of organic matter transformation

Supplementary Files 
This is a list of supplementary files associated with this preprint. Click to download.

- GraphicalAbstract.png 